\title{
Estimating climate change effects on net primary production of rangelands in the United States
}

\author{
Matthew C. Reeves • Adam L. Moreno • \\ Karen E. Bagne $\cdot$ Steven W. Running
}

Received: 31 January 2014 / Accepted: 17 August 2014 / Published online: 2 September 2014

(C) The Author(s) 2014. This article is published with open access at Springerlink.com

\begin{abstract}
The potential effects of climate change on net primary productivity (NPP) of U.S. rangelands were evaluated using estimated climate regimes from the $\mathrm{A} 1 \mathrm{~B}, \mathrm{~A} 2$ and $\mathrm{B} 2$ global change scenarios imposed on the biogeochemical cycling model, Biome-BGC from 2001 to 2100. Temperature, precipitation, vapor pressure deficit, day length, solar radiation, $\mathrm{CO}_{2}$ enrichment and nitrogen deposition were evaluated as drivers of NPP. Across all three scenarios, rangeland NPP increased by $0.26 \%$ year $^{-1}\left(7 \mathrm{~kg} \mathrm{C}^{-1}\right.$ year $\left.^{-1}\right)$ but increases were not apparent until after 2030 and significant regional variation in NPP was revealed. The Desert Southwest and Southwest assessment regions exhibited declines in NPP of about $7 \%$ by 2100, while the Northern and Southern Great Plains, Interior West and Eastern Prairies all experienced increases over $25 \%$. Grasslands dominated by warm season (C4 photosynthetic pathway) species showed the greatest response to temperature while cool season (C3 photosynthetic pathway) dominated regions responded most strongly to $\mathrm{CO}_{2}$ enrichment. Modeled NPP responses compared favorably with experimental results from $\mathrm{CO}_{2}$ manipulation experiments and to NPP estimates from the Moderate Resolution Imaging Spectroradiometer (MODIS). Collectively, these results indicate significant and asymmetric changes in NPP for U.S. rangelands may be expected.
\end{abstract}

Electronic supplementary material The online version of this article (doi:10.1007/s10584-014-1235-8) contains supplementary material, which is available to authorized users.

M. C. Reeves $(\square)$

USDA Forest Service, Rocky Mountain Research Station, Human Dimensions Program, PO Box 7669, 200

E. Broadway, Missoula, MT 59807, USA

e-mail: mreeves@fs.fed.us

A. L. Moreno

Institute of Silviculture, University of Natural Resources and Life Sciences - Vienna, Peter Jordanstr 82,

A-1190 Vienna, Austria

K. E. Bagne

Department of Biology, Kenyon College, Gambier, OH 43022, USA

S. W. Running

Regents Professor Steven W. Running, Director, Numerical Terradynamic Simulation Group, Department of Ecosystem and Conservation Sciences, University of Montana, Missoula, MT 59812, USA 


\section{Introduction}

Net primary productivity (NPP), or the rate of assimilation of $\mathrm{CO}_{2}$ through photosynthesis, is the fundamental link between the atmosphere and the biosphere. Human activities emit large quantities of $\mathrm{CO}_{2}$ into the atmosphere and alter climate patterns, which directly impacts NPP (Greer et al. 1995; Nakićenović et al. 2000). Furthermore, humans already consume almost a quarter of potential NPP (Haberl et al. 2007).

Rangelands provide a multitude of biological and social benefits that are a key component of global sustainability (Reynolds et al. 2007; Munasinghe 2009). The future of goods and services derived from rangelands, such as fuelwood and protein, however, is uncertain as are impacts expected from climate change. In general, across the extent of U.S. rangelands, climate change is being expressed as warmer temperatures and variable precipitation which are expected to continue into the foreseeable future (IPCC 2013). Low and variable precipitation, extreme temperatures and high evaporative demands render most rangelands inherently vulnerable to degradation under climate change (Reynolds et al. 2007; Korner 2000; Le Houérou 1996; Sala et al. 2000). Thus, projections of NPP in rangelands are fundamental to understanding climate change impacts on global ecosystems and sustainability of goods and services.

In rangelands, productivity is mainly determined by the distribution of precipitation and resultant effects on soil water availability (Campbell et al. 1997; Knapp et al. 2001; Izaurralde et al. 2011). Soil water availability is subsequently dependent on other environmental factors such as temperature, vapor pressure deficit, soil properties and $\mathrm{CO}_{2}$ concentration via effects on stomatal conductance (Izaurralde et al. 2011; Morgan et al. 2004b, 2011). Elevated $\mathrm{CO}_{2}$ may increase NPP in semi-arid regions by increasing plant water use efficiency (Fay et al. 2003; Izaurralde et al. 2011). Furthermore, plant species vary in their response to these factors and alteration of NPP can be expected in the future as species respond to climate change through range shifts or local population dynamics (Morgan et al. 2007; Polley et al. 2012).

Much of our present knowledge, empirical evidence, and expectations of NPP response to climate change are deduced from localized experiments, which have primarily focused on forests or crops. The limited applicability of most experimental studies, however, prohibits confident extrapolation to a comprehensive regional picture of future trends of NPP (Norby and Luo 2004). Therefore, regional analyses should consider interactions of biophysical factors, such as nitrogen deposition and elevated $\mathrm{CO}_{2}$, (Hungate et al. 2003; Milchunas et al. 2005; Maestre et al. 2012; Wouter et al. 2012) to improve understanding of spatial variability in response of NPP to climate change and to identify areas where adaptation measures may be required (Fussel and Klein 2006; Cleland et al. 2007; Joyce et al. 2013). In response to this need, a regional analysis of NPP, projected to 2100, for rangelands of the coterminous U.S. was conducted using the ecosystem process model, Biome-BGC (Running and Hunt 1993). Dominant metabolic pathway was used to broadly indicate influence of current species composition (Epstein et al. 2002; Zavaleta et al. 2003; Polley et al. 2012). Current species composition, coupled with Biome-BGC, and climate projections from four general circulation models (GCM) under three emissions scenarios were used to model NPP at a spatial scale of 5 arc minutes (about 9.3 by $7.1 \mathrm{~km}$ at $40^{\circ}$ north latitude). In addition, climate and dominant drivers of NPP were characterized, temporally and spatially, across U.S. rangelands for each GCM and scenario. Finally, spatial and temporal patterns of changes in NPP, from a contemporary baseline without regard for possible future land cover changes or potential disturbance regimes, were quantified. 


\section{Materials and methods}

\subsection{Climate data}

A spinup simulation was performed to create steady state conditions for the ecosystems from which future projections began. Biome-BGC requires daily estimates of maximum and minimum temperature, precipitation, daylength, solar radiation and vapor pressure deficit. Temperature and precipitation data for the spinup period were obtained from the PRISM (Parameter-elevation Regressions on Independent Slopes Model) project (Daly et al. 2000). Vapor pressure deficit, solar radiation and day length are not produced by PRISM. These variables were created from PRISM data using the MT-CLIM algorithms (Kimball et al. 1997). The resulting climatological data for the spinup were developed at a daily temporal resolution and matched the spatial resolution of the GCM data. The delta method (Mote and Salathé, 2009) was used to temporally downscale the monthly PRISM Data, from 1940-2000, to a daily temporal resolution which were used for the spinup period (Supplementary Material (SM) 1).

The projection covered three emissions scenarios from 2001-2100 derived from the Third Intergovernmental Panel on Climate Change (IPCC) Assessment Special Report on Emission Scenarios (Nakićenović et al. 2000). These emissions scenarios encompass different assumptions regarding socioeconomic drivers such as gross domestic product, population growth, technological innovation and greenhouse gas emissions (SM 2). For the present study, the IPCC scenarios corresponded to the A1B, A2, and B2 scenarios. Climate data processed by Coulson et al. (2010a, b) emanate from a series of GCM's including the Climate Centre for Modelling and Analysis (GCGM2), Australia's Commonwealth Scientific and Industrial Research Organisation (CSIRO MK2), Hadley Centre for Climate Prediction and Research UK (HadCM3) and Model for Interdisciplinary Research on Climate (MIROC 3.2). Coulson et al. (2010a, b) spatially downscaled data from a selected suite of GCM's used in the Fourth IPCC Assessment resulting in estimates of monthly averaged maximum and minimum temperature and precipitation at the 5 arc minute spatial resolution. The GCM data were spatially downscaled by Coulson et al. $(2010 \mathrm{a}, \mathrm{b})$ using the ANUSPLIN software to fit a twodimensional spline function at each month's for each climate variable. These procedures are described at length in Joyce et al. (2011, 2014).

As with the PRISM data monthly estimates of maximum and minimum temperature and precipitation from the GCM's were temporally downscaled to a daily time-step to accommodate the needs of Biome-BGC using the delta method (SM 1). From these daily data, estimates of daylength, solar radiation and vapor pressure deficit were derived using the MT-CLIM algorithms.

\subsection{Spatial domain of analysis}

Defining the extent and composition of the area for estimating potential future rangeland NPP required two steps (SM 1). For the first step, the spatial extent of rangelands in the coterminous U.S. was identified from Reeves and Mitchell (2011) (SM 3). In the second step, the relative abundance of $\mathrm{C} 3, \mathrm{C} 4$, and shrub plant functional types were quantified at each pixel in the rangeland domain from Step 1. Cross-hatched regions depicted in SM 3 were used for validation and comparison purposes but not for describing NPP response to climate change, because, although shrub or herb dominated, these regions are outside the rangelands study area as defined from Reeves and Mitchell (2011). All modeling of NPP projections was conducted at the 5 arc minute pixel level. Results, however, were often aggregated to larger spatial extents including the six assessment regions depicted in SM 3. 
2.3 Nitrogen deposition, carbon dioxide concentrations, and soils

The emission scenarios included decadal, aspatial estimates of $\mathrm{NO}_{\mathrm{x}}$ emissions (SM4). Decadal values were linearly interpolated to estimate annual values. Further, nitrogen deposition was assumed to increase at the same rate as nitrogen emissions, therefore, permitting the rate of increase of nitrogen emissions as a proxy for the rate of increase of nitrogen deposition. Since these data were tabular, data from Holland et al. (2005), describing current patterns of nitrogen deposition, were used to apportion projections of deposition across the landscape for each scenario. This ensured that the spatial pattern and relative magnitude of nitrogen deposition was held constant throughout the projection, although total deposition was based on the temporal trends found in estimated nitrogen emissions for each scenario (SM 4).

As with nitrogen emissions, decadal estimates of $\mathrm{CO}_{2}$ concentrations accompanied each IPCC emissions scenario and are represented in SM 4, which shows the trajectory of $\mathrm{CO}_{2}$ concentrations across the projection. Estimates of decadal $\mathrm{CO}_{2}$ concentration were aspatial and applied symmetrically to every pixel as $\mathrm{CO}_{2}$ is assumed to be distributed homogenously across the study area.

To provide linkages with the forthcoming Fifth IPCC Assessment Report (AR5) (Moss et al. 2010; Rogelj et al. 2012) (http://www.ipcc.ch/activities/activities.shtml\#.Ug6Z0UG1Hh4), suggested linkages between the $\mathrm{CO}_{2}$ concentrations found in the Representative Concentration Pathways and the socioeconomic scenarios used in the present study is provided in SM 4. Our linkages are based on similarities of $\mathrm{CO}_{2}$ concentration by 2100 , and differ, for the B2 scenario, from the linkages conducted by Rogelj et al. (2012).

The final parameters needed to simulate future NPP with Biome-BGC included soil data, which were derived from the State Soil Geographic database (STATSGO) (U.S. Department of Agriculture and Natural Resources Conservation Service NRCS 1994). The percentage of sand, silt and clay and depth to bedrock were quantified for the study area. These data were gridded to the 5 arc minute resolution to match all other spatially explicit simulation parameters. These soils data are used by Biome-BGC to control belowground processes such as decomposition and water balance.

\subsection{Simulating vegetation productivity}

Using the present vegetation distribution, climate, $\mathrm{CO}_{2}, \mathrm{NO}_{\mathrm{x}}$, and soils data as described above, estimates of annual NPP on U.S. rangelands were produced by simulating ecosystem dynamics through application of Biome-BGC across the entire projection for every GCM and scenario combination (SM 5). The contemporary distribution of plant functional types and photosynthetic pathways were held constant throughout the projection. This was done because it isn't feasible to make spatially-explicit, realistic assumptions about vegetation change over a century time span over the study area. Therefore, results only reflect changes in $\mathrm{CO}_{2}$ concentration, nitrogen deposition, and climate variables, which was the focus of the study. Change in NPP at each pixel was characterized by the slope of the linear trend with respect to time (2001-2100).

\subsection{Analysis of NPP and drivers of change}

Though the Biome-BGC simulations were conducted across the entire projection for every GCM and scenario combination, NPP data were averaged across each GCM to produce scenario-level results. Biome-BGC was run for each emission scenario using climate projections from each of several GCMs. NPP derived from different GCMs was then averaged for 
each emission scenario. The spatial differences between the various GCM's are intensively explored in Joyce et al. (2011) and are therefore omitted here. Spearman correlation coefficients were computed at each pixel to identify which of the aforementioned drivers was most closely related to patterns of NPP through time for each scenario. The bioclimatic factor with the highest correlation to estimated NPP was retained and considered the dominant driver of change in productivity. In a similar fashion, temporal trends in NPP were described using a linear trend to determine the direction and magnitude of change. Precipitation and temperature were also evaluated using a linear trend enabling the direction and magnitude of change relative to present day conditions to be quantified. For NPP and climate data, the response of the three emissions scenarios were averaged together and differences among them were represented as standard deviations about the mean.

\subsection{Quantifying model agreement}

Direct validation of projected estimates of NPP was not possible because no spatially extensive field-referenced estimates of NPP currently exist for coterminous U.S. rangelands. There are data, however, from remote sensing instruments that can be used to characterize agreement among NPP estimates. Net primary productivity derived from the Moderate Resolution Imaging Spectroradiometer (MODIS) satellite has been used for evaluating NPP and biomass dynamics of rangeland biomes (Heinsch et al. 2006; Reeves et al. 2006; Zhang et al. 2010). The MODIS-derived NPP estimates are available globally at $1 \mathrm{~km}^{2}$ spatial resolution and were compared with NPP derived using Biome-BGC within the regions identified in SM 3. This analysis does not constitute an accuracy assessment but provides insight into locations where model results may be questionable or, conversely, where they are more reliable.

\section{Results}

\subsection{Projected climatic trends}

Average annual temperature increased (Fig. 1a) in each of the three scenarios but varied considerably by region (Fig. 1b). Near 2018, the average annual temperature was projected to surpass the upper limit of historic variation measured since 1940 and continued to rise steadily throughout the projection. The Interior West and Eastern Prairie assessment regions exhibited the greatest amount of warming $\left(0.032{ }^{\circ} \mathrm{C} \pm 0.002\right.$ and 0.003 years $^{-1}$, respectively). Some ecological subsections (Bailey and Hogg 1986) in the Interior West, at the upper altitude limits of the coterminous U.S., experienced significant increases in temperature, often exceeding $4{ }^{\circ} \mathrm{C}$ by the end of the projection. The Northern Great Plains, Southern Great Plains, and Southwest all warmed at about the same rate $\left(\sim 0.03{ }^{\circ} \mathrm{C} \pm 0.002,0.0001,0.001\right.$ year $^{-1}$, respectively), while the Desert Southwest warmed at the slowest rate $\left(0.02{ }^{\circ} \mathrm{C} \pm 0.002\right.$ years $\left.^{-1}\right)$. Despite these generalities, significant sub-regional variation in temperature trends was exhibited (Fig. 1b).

In contrast to temperature, projected changes in precipitation were not as dramatic, but more variable, in terms of scenario differences. From a national perspective, precipitation remained close to or within the historical range of variability of precipitation for all three scenarios across the entire projection (Fig. 1c). Overall, the mean precipitation difference from 2001 to 2100 across all three scenarios was $-1.5 \%$ with a standard deviation of $5.2 \%$. This standard deviation represents the variability inherent among precipitation projections associated with 

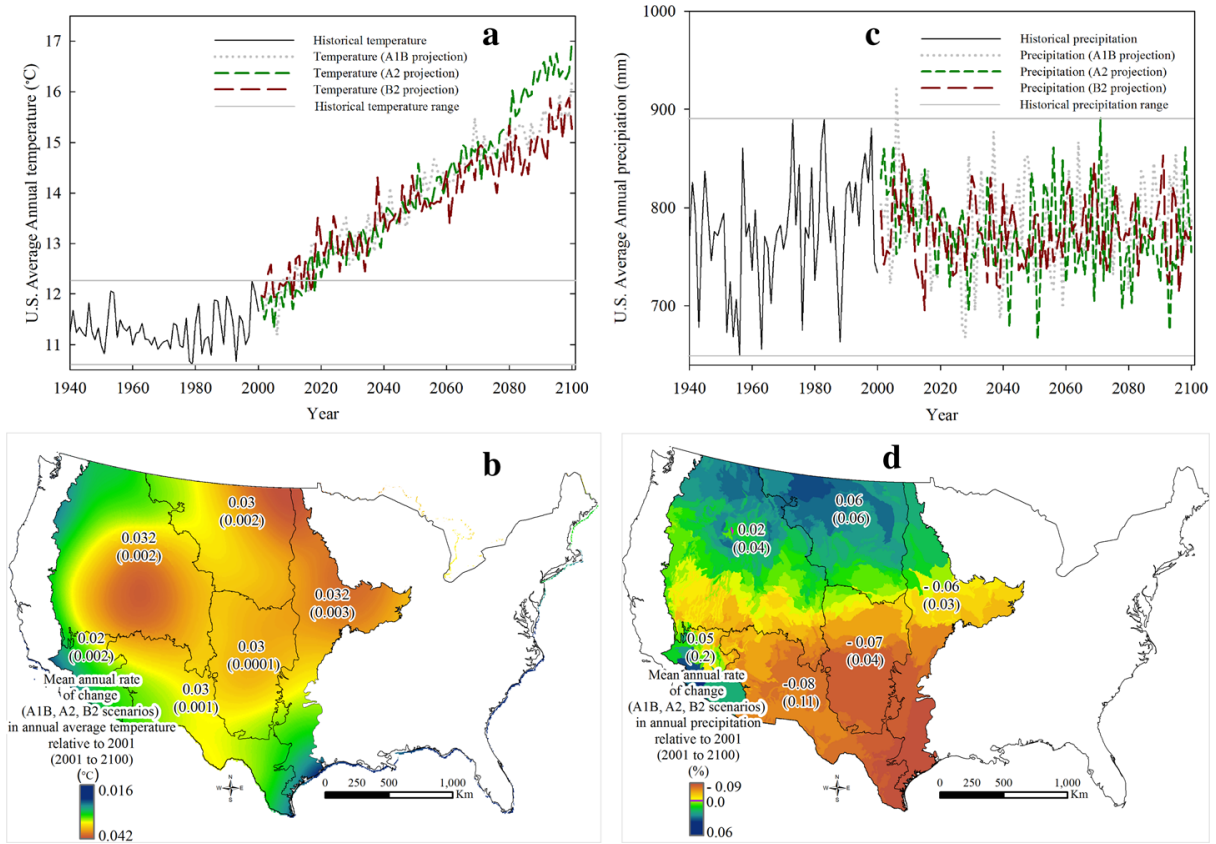

Fig. 1 Projected temperature in ${ }^{\circ} \mathrm{C}$ (a) and precipitation in $\mathrm{mm}$ (c) on U.S. rangelands to 2100 for $\mathrm{A} 1 \mathrm{~B}, \mathrm{~A} 2$, and B2 emissions scenarios. Spatial patterns of rates of change (slope of linear regression) from 2001 to 2100 in temperature $\left({ }^{\circ} \mathrm{C}\right)(\mathbf{b})$ and precipitation $(\%)(\mathbf{d})$ for $\mathrm{A} 1 \mathrm{~B}, \mathrm{~A} 2$, and $\mathrm{B} 2$ emissions scenarios. Mean rate of change (SD) across all emissions scenarios in a region are represented in white numbers

the three scenarios. Among the assessment regions, the Northern Great Plains had the greatest rate of precipitation increase (Fig. 1d) but was also highly variable $\left(0.06 \% \pm 0.06\right.$ years $\left.^{-1}\right)$ between scenarios. Annual precipitation in the Eastern Prairies and Southern Great Plains declined at an average rate of -0.07 and $-0.06 \%$ year $^{-1}$ and exhibited less variability than in the northern Great Plains. The Southwest assessment region exhibited the greatest decrease in annual precipitation, albeit with high variability between scenarios. The mean precipitation response was positive in the Desert Southwest, but the region exhibited extreme variability (standard deviation of 4 times the mean).

\subsection{Vegetation productivity}

The overall NPP trends suggest increases of 16,19 and $15 \%$, for the A1B, A2, and B2 scenarios, respectively, for all coterminous U.S. rangelands by 2100 (Fig. 2). Although the trend for the entire projection was strongly positive with an average annual increase of $0.26 \%$, NPP did not begin moving in a positive direction until approximately 2030 (Fig. 2). The earlier stages of the projection suggest decreasing NPP from present day to the 2030s while tracking the trend in precipitation (Fig. 3). After this initial lag, NPP begins to increase steadily and diverge from the trend in precipitation (Fig. 3). The divergence of the NPP response from precipitation is related to $\mathrm{CO}_{2}$ fertilization and ever increasing temperatures (Fig. 3). Lengthened growing season increases opportunity for $\mathrm{CO}_{2}$ fixation if moisture is sufficiently abundant (Christensen et al. 2004). Thus, losses due to moisture limitations in the southern extent of the study area begin to be offset and surpassed by increases in NPP due to increased 
Fig. 2 Relative change in decadal NPP from baseline (2001-2010) for the period 2001-2100 averaged across A1B, A2, and B2 emissions scenarios

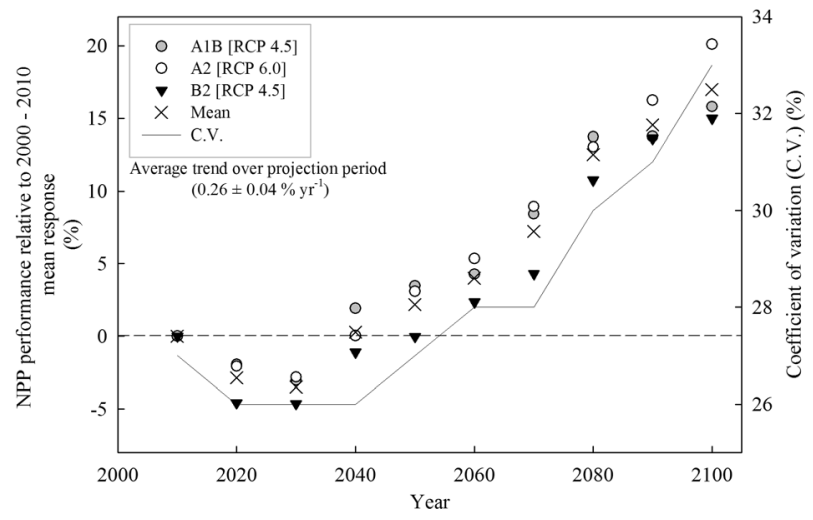

growing season length in northern latitudes beginning in the 2030s. The amount of disagreement among scenarios reached its apex in the last decade of the simulation period (Fig. 2). These general trends, however, bely patterns across rangelands in the western United States (Fig. 4, SM 6).

The NPP of the Southern Great Plains, Northern Great Plains, and Eastern Prairies increased at roughly the same rate of $3.6 \%$ increase per decade while the Interior West increased the most at $4.5 \%$ per year. NPP of the Desert Southwest and Southwest regions decreased slightly during the projection at -0.67 and $-1.05 \%$ per decade, respectively. While average regional responses act as a general guide, within each assessment region there was significant variation in terms of the NPP response. For example, declines in productivity for southern and southwestern Texas and central Arizona often exceeded $11 \%$ during the projection (Fig. 4).

Interpretation of information portrayed in Fig. 4 requires evaluation of the deviation or disagreement among the scenarios in terms of NPP response. In many instances, parts of the Desert Southwest and Southwest experienced significant declines in NPP, yet exhibited high disagreement among scenarios suggesting that the ultimate fate of NPP of these regions is more uncertain. In contrast, the variation in NPP response across the northern and southern Great Plains among the three scenarios was quite low.

Fig. 3 Normalized 10-year moving average of trends in annualized $\mathrm{NPP}, \mathrm{CO}_{2}$, precipitation, maximum temperature, and minimum temperature

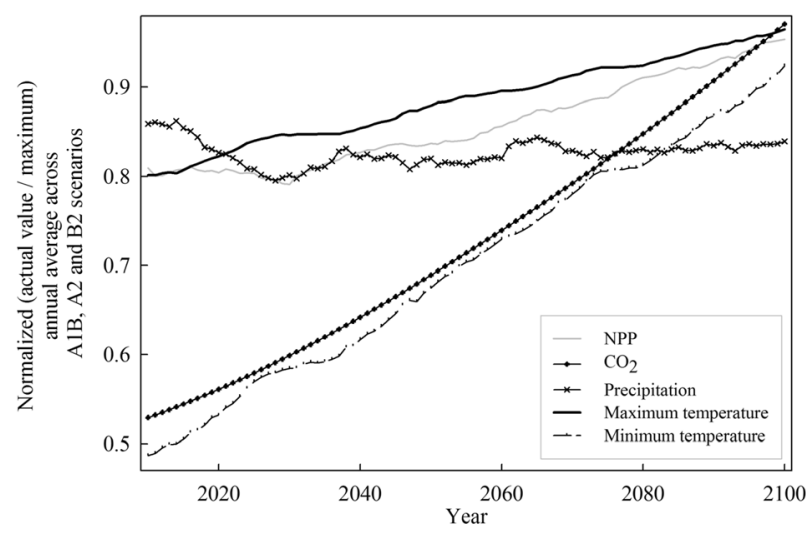



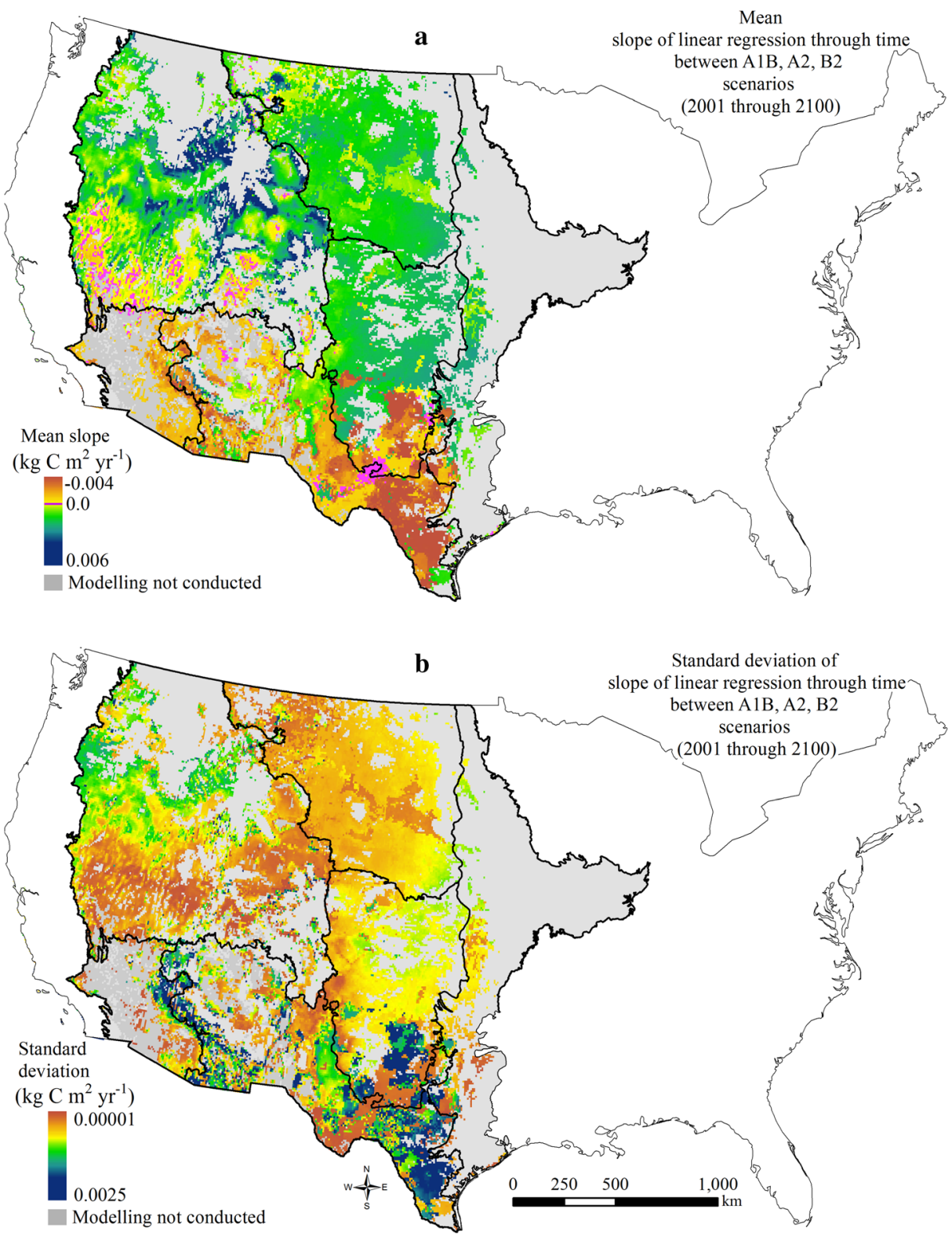

Fig. 4 Mean slope of linear regression of NPP trend for U.S. rangelands to 2100 (a). Standard deviation of the mean slope of linear regression of NPP trend to 2100 for A1B, A2, and B2 emissions scenarios (b)

\subsection{Modeled NPP agreement with other sources}

NPP derived by Biome-BGC from 2000 to 2012 had similar trends as MODIS-derived NPP from the same time period (SM 7). In SM 7, the relationship between NPP in all regions and MODIS-derived NPP are shown. Although NPP derived by Biome-BGC from 2000 to 2012 compared favorably with MODIS-derived NPP from the same time period (trend is similar but 
positively biased), the Biome-BGC-derived NPP was considerably higher. Though BiomeBGC-derived NPP compared reasonably well with MODIS and experimental results, multiple sources of uncertainty and several caveats should be considered.

\subsection{Drivers of change}

Relations between bioclimatic drivers and projected NPP trends are shown in Fig. 5. The Northern and Southern Great Plains and Eastern Prairies were characterized as grassdominated expanses comprised of mixtures of C4 (warm season) species (SM 3) and C3 (cool season) species in greatly varying proportions. Data portrayed in SM 3 indicate the proportional abundance of differing photosynthetic pathways as many areas are mixtures of species. Net primary productivity of these regions tended to be most influenced by temperature (Fig. 5), but the southern end of the Southern Great Plains and eastern edge of Northern Great Plains experienced change most related to precipitation. In contrast, the Interior West, dominated by $\mathrm{C} 3$ grasses or shrubs, tended to be most highly correlated with $\mathrm{CO}_{2}$ in terms of NPP through time. As expected, NPP trends of the southerly rangeland extent were most highly correlated with precipitation and water relations. Nitrogen deposition (not shown; SM8) was rarely found to be a greater determinant of productivity than climatic or $\mathrm{CO}_{2}$ concentration factors, which may reflect relatively low levels of projected change compared with other factors.

\section{Discussion}

Overall, the balance of changing NPP across U.S. rangelands was positive with gains outpacing losses by the 2030s. Trends of increasing NPP were observed for northern and central regions while decreasing NPP was apparent across the southwestern U.S. (Fig. 4). Additionally, NPP was projected to increase proportionally more at high elevations,

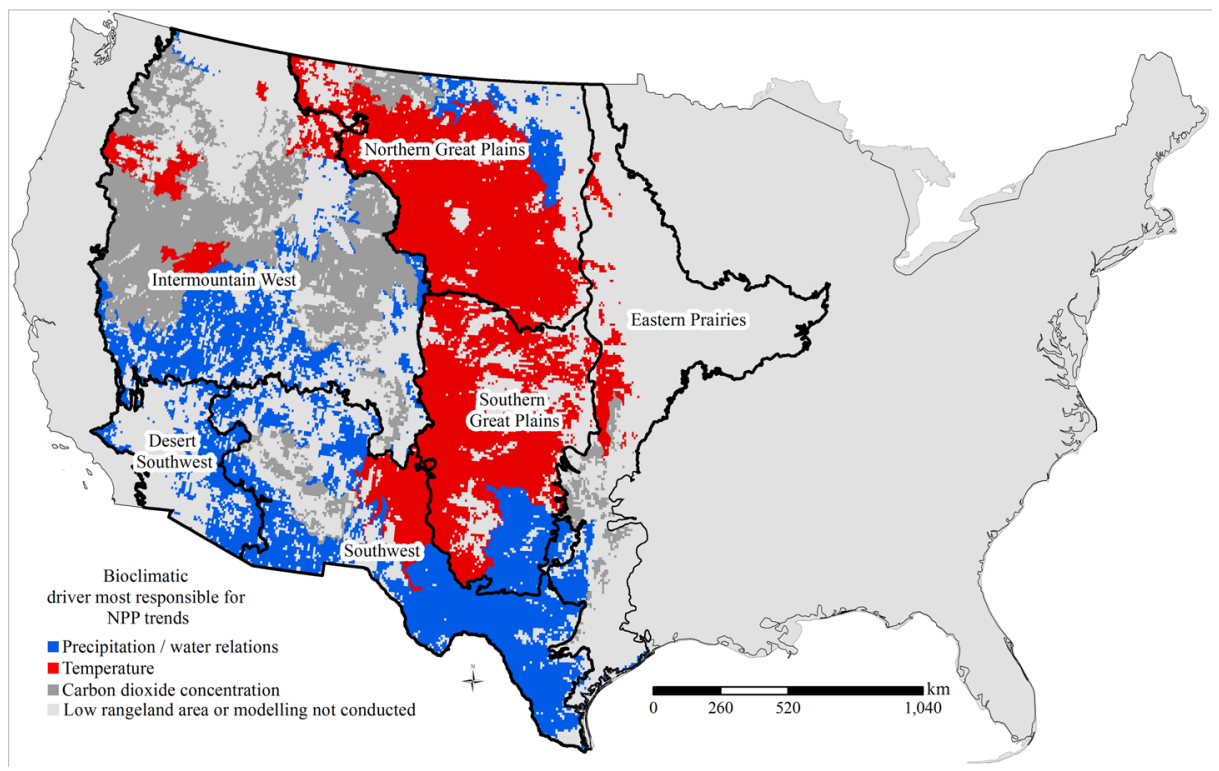

Fig. 5 Bioclimatic driver with the highest correlation to estimated NPP trends 
particularly in the Interior West (Fig. 4). The proportionally larger increase in NPP at higher elevations was similarly noted by Riedo et al. (2001) in alpine rangeland landscapes at double ambient $\mathrm{CO}_{2}$ conditions. Drivers of changing productivity followed a geographic pattern resembling that of NPP with the primary driver being precipitation in southern regions, temperature in northern regions, and $\mathrm{CO}_{2}$ in the Interior West. Nitrogen deposition had relatively little influence at these scales.

Similar to our results, Polley et al. (2013) suggested that NPP will decrease in southern rangelands in response to warmer temperatures and declining precipitation, and will increase on northern rangelands as a result of warmer temperatures and greater precipitation. Model results could not be directly validated with NPP measures across U.S. rangelands, but several studies provide comparable localized results. Results from the Prairie Heating and $\mathrm{CO}_{2}$ Enrichment (PHACE) study (Morgan et al. 2011) for a mixed-grass prairie in Wyoming compare favorably with our results. Morgan et al. (2011) reported an increase of aboveground productivity by an average of $33 \%$ over 3 years, which substantiates our estimate of a $28 \%$ increase in productivity for the Northern Great Plains by 2100 in response to a similar total increase in $\mathrm{CO}_{2}$. Similarly in a Colorado shortgrass steppe, enrichment of $\mathrm{CO}_{2}$ to double ambient levels positively affected the growth of $\mathrm{C} 3$ grasses and significantly increased aboveground biomass (Morgan et al. 2007). For tallgrass prairie, Owensby et al. (1999) found that elevated $\mathrm{CO}_{2}$ could increase productivity of above-and below-ground biomass, but response was dependent on water stress. Aboveground NPP increased with $\mathrm{CO}_{2}$ enrichment only during very wet years in the Mojave desert, but was unchanged over a 10 year period suggesting $\mathrm{CO}_{2}$ has little influence in a perennial plant community characterized by low plant cover and rare recruitment events (Newingham et al. 2013; Newingham et al. 2014). These findings are consistent with results from our model and suggest that desiccation effects of increased temperature can be offset to some extent by $\mathrm{CO}_{2}$ enrichment via reduced transpirational demand (Leakey 2009; Morgan et al. 2004b, 2011; Woodward and Kelly 2008), but responses in arid regions are less certain. Within the range evaluated here, $\mathrm{CO}_{2}$ concentration ultimately reduces moisture limitations via greater water use efficiency (Bachelet et al. 2001; Christensen et al. 2004; Morgan et al. 2008, 2011; Polley et al. 2003). NPP may decrease, however, if $\mathrm{CO}_{2}$ becomes sufficiently abundant to reduce $\mathrm{N}$ mineralization rates, through greater production of structural components, and $\mathrm{N}$ availability to plants (King et al. 2004; Morgan et al. 2001, 2004a, 2007; Milchunas et al. 2005).

It is worth noting that all models are a simplification of reality and interpretation of model results needs to consider uncertainty, inputs, and model assumptions. Differences among the GCM's used here have been extensively examined (Randall et al. 2007, Tabor and Williams 2010). Of importance for interpreting model output for the present study is the increasing disparity among models as time progresses and the more pronounced variation in arid regions where precipitation is the primary driver of NPP change. Projections of productivity in desert areas, omitted here, are additionally problematic, because Biome-BGC does not evaluate response of Crassulacean Acid Metabolism (CAM) plants (Running and Hunt 1993). Although more uncertain than projections for northern regions, we note that any decrease in productivity in arid regions is likely to have large ecological impacts because NPP is already low (Tietjen et al. 2010).

Although Biome-BGC models the complex interaction of water, carbon, and nitrogen between the soil and atmosphere, it does not model all factors determining rangeland productivity and vegetation type is held constant. Changes in species assemblages, disturbance regimes, and land use will undoubtedly affect future NPP in complex and unexpected ways (Morgan et al. 2007; Suttle et al. 2007; Walther 2010). Thus, projections presented here represent a potential for NPP based on climate and soils in the absence of other change. NPP 
derived by Biome-BGC from 2000-2012 compared reasonably well with MODIS-derived NPP from the same time period, although the Biome-BGC-derived NPP was considerably higher (SM 7). This is not necessarily a reflection of poor model performance because Biome-BGCderived NPP represents a kind of potential rather than actual NPP. Satellite data, such as MODIS, reflects land management effects on vegetation productivity and also relies on models to estimate NPP. In contrast, Biome-BGC models NPP based on climate and other biophysical drivers without an implicit link to land management practices such as livestock grazing.

In this vein, the present work is novel given the spatially explicit application of BiomeBGC accounting for multiple and interacting factors simultaneously applied across a large region representing diverse climate futures. Results demonstrate the importance of regional or national analyses aimed at understanding the response of rangeland NPP to climate change, which has important implications for sustaining livelihoods and food security (Izaurralde et al. 2011; Polley et al. 2013). For example, on native pastures in Queensland, Australia, Hall et al. (1998) estimated that the combined effects of warmer temperature and $\mathrm{CO}_{2}$ enrichment could raise carrying capacity of livestock by $3-45 \%$ depending on the rainfall scenario. Others have predicted a reduction in livestock production even with increasing NPP, due to concurrent reductions in plant nitrogen content, higher production variability, and lower animal performance (Hanson et al. 1993). Although the overall increase in potential NPP for rangelands is potentially important, localized benefits should not be used as evidence to suggest that mitigation aimed at reducing greenhouse gas concentrations does not need to be pursued. On the contrary, the complexity of estimating future rangeland NPP indicates a strong need for improved forecasting tools and coordinated field monitoring (Luo et al. 2011).

Acknowledgments We would like to acknowledge the United States Department of Agriculture, Forest Service, Rangeland Management and Vegetation Ecology Department for their financial support for this project. We thank Dr. John Mitchell for providing information for improving the manuscript. In addition, we thank anonymous reviewers that provided useful suggestions for improving the manuscript.

Open Access This article is distributed under the terms of the Creative Commons Attribution License which permits any use, distribution, and reproduction in any medium, provided the original author(s) and the source are credited.

\section{References}

Bachelet D, Neilson RP, Lenihan JM, Drapek RJ (2001) Climate change effects on vegetation distribution and carbon budget in the United States. Ecosystems 4:164-185

Bailey RG, Hogg HC (1986) A world ecoregions map for resource reporting. Environ Conserv 13:195-202

Campbell BD, Stafford-Smith DM, McKeon GM (1997) Elevated $\mathrm{CO}_{2}$ and water supply interactions in grasslands: A pastures and rangelands management perspective. Glob Chang Biol 3:177-187

Chiesi M, Maselli F, Moriondo M, Fibbi L, Bindi M, Running SW (2007) Application of BIOME-BGC to simulate Mediterranean forest processes. Ecol Model 206:179-190

Christensen L, Coughenour MB, Ellis JE, Chen ZZ (2004) Vulnerability of the Asian typical steppe to grazing and climate change. Clim Chang 63:351-368

Cleland EE, Chuine I, Menzel A, Mooney HA, Schwartz MD (2007) Shifting plant phenology in response to global change. Trends Ecol Evol 22:357-365

Comer PJ, Schulz KA (2007) Standardized ecological classification for mesoscale mapping in the southwestern united states. Rangel Ecol Manage 60:324-335

Coulson DP, Joyce LA, Price DT, McKenney DW, Siltanen RM, Papadopol P, Lawrence K (2010a) Climate Scenarios for the conterminous United States at the 5 arc minute grid spatial scale using SRES scenarios $\mathrm{A} 1 \mathrm{~B}$ and A2 and PRISM climatology. Department of Agriculture, Forest Service, Rocky Mountain Research Station, Fort Collins, Colorado. Available: http://www.fs.fed.us/rm/data_archive/dataaccess/US ClimateScenarios_grid_A1B_A2_PRISM.shtml [2014, April 23] 
Coulson DP, Joyce LA, Price DT, McKenney DW (2010b) Climate Scenarios for the conterminous United States at the 5 arc minute grid spatial scale using SRES scenario B2 and PRISM climatology. Department of Agriculture, Forest Service, Rocky Mountain Research Station, Fort Collins, Colorado. Available: http:// www.fs.fed.us/rm/data_archive/dataaccess/US_ClimateScenarios_grid_B2_PRISM.shtml[2014, April 23]

Daly C, Taylor GH, Gibson WP, Parzybok TW, Johnson GL, Pasteris PA (2000) High-quality spatial climate data sets for the United States and beyond. T ASAE 43:1957-1962

De Pury DGG, Farquhar GD (1997) Simple scaling of photsynthesis from leaves to canopies without the errors of big-leaf models. Plant Cell Environ 20:537-557

Epstein HE, Gill RA, Paruelo JM, Lauenroth WK, Jia GJ, Burke IC (2002) The relative abundance of three plant functional types in temperate grasslands and shrublands of north and South America: effects of projected climate change. J Biogeogr 29:875-888

Farquhar GD, Caemmerer SV, Berry JA (1980) A Biochemical Model of Photosynthetic $\mathrm{CO}_{2}$ Assimilation in Leaves of C3 Species. Planta 149:78-90

Fay PA, Carlisle JD, Knapp AK, Blair JM, Collins SL (2003) Productivity responses to altered rainfall patterns in a C-4-dominated grassland. Oecologia 137:245-251

Fussel HM, Klein RJT (2006) Climate change vulnerability assessments: An evolution of conceptual thinking. Clim Chang 75:301-329

Golinkoff, J (2010) Biome BGC version 4.2: Theoretical Framework of Biome-BGC. Numerical Terradynamic Simulation Group Modeling and Monitoring Ecosystem Function at Multiple Scales. Biome-BGC. Available: http://www.ntsg.umt.edu/project/biome-bgc. [2014, May 1]

Greer DH, Laing WA, Campbell BD (1995) Photosynthetic responses of 13 pasture species to elevated $\mathrm{CO}_{2}$ and temperature. Aust J Plant Physiol 22:713-722

Haberl H, Erb KH, Krausmann F et al (2007) Quantifying and mapping the human appropriation of net primary production in earth's terrestrial ecosystems. P Natl Acad Sci USA 104:12942-12947

Hall W, Mckeon GM, Carter J, Day KA, Howden SM, Scanlan JC (1998) Climate change in Queensland's grazing lands: Ii. An assessment of the impact on animal production from native pastures. Range J 20:177-205

Hana Q, Geping L, Chaofan L, WenQiang X (2014) Modeling the grazing effect on dry grassland carbon cycling with Biome-BGC model. Ecol Complex 17:149-157

Hanson JG, Baker BB, Bourdon RM (1993) Comparison of the effects of different climate change scenarios on rangeland livestock production. Agric Sys 41:487-502

Heinsch FA, Ficcuito DM, Law BE et al (2006) Evaluation of remote sensing based terrestrial productivity from MODIS using regional tower eddy flux network observations. IEEE T Geosci Remote 44:1908-1925

Holland E, Braswell B, Sultzman J, Lamarque JF (2005) Nitrogen deposition onto the United States and Western Europe: synthesis of observations and models. Ecol Appl 15:38-57

Hungate BA, Dukes JS, Shaw MR, Luo Y, Field CB (2003) Nitrogen and Climate Change. Science 302:1512-1513

Jolly WM, Graham JM, Michaelis A, Nemani R, Running SW (2005) A flexible, integrated system for generating meteorological surfaces derived from point sources across multiple geographic scales. Environ Model Softw 20:873-882

Joyce LA, Price DT, McKenney DW, Siltanen RM, Papadopol P, Lawrence K, Coulson DP (2011) High Resolution Interpolation of Climate Scenarios for the Conterminous USA and Alaska Derived from General Circulation Model Simulations. USDA For Serv Gen Tech Rep RMRS-GTR-263, p 87

Joyce LA, Briske DD, Brown JR, Polley HW, McCarl BA, Bailey DW (2013) Climate Change and North American Rangelands: Assessment of Mitigation and Adaptation Strategies. Rangel Ecol Manage 66:512-528

IPCC (2013) Climate Change 2013: The Physical Science Basis. Contribution of Working Group I to the Fifth Assessment Report of the Intergovernmental Panel on Climate Change. In: Stocker TF, Qin D, Plattner G-K, Tignor M, Allen SK, Boschung J, Nauels A, Xia Y, Bex V, Midgley PM (eds) Cambridge University Press, Cambridge, United Kingdom and New York, NY, USA, pp 1535

Izaurralde RC, Thomson AM, Morgan JA, Fay PA, Polley HW, Hatfield JL (2011) Climate Impacts on Agriculture: Implications for Forage and Rangeland Production. Agron J 103:371-381

Joyce LA, Price DT, Coulson DP, McKenney DW, Siltanen MR, Papadopol P, Lawrence K (2014) Projecting Climate Change in the United States: A Technical Document Supporting the Forest Service RPA 2010 Assessment. USDA For Serv Gen Tech Rep RMRS-GTR-320, p 85

Kimball JS, Running SW, Nemani R (1997) An improved method for estimating surface humidity from daily minimum temperature. Agr Forest Meteorol 85:87-98

King JY, Mosier AR, Morgan JA, LeCain DR, Milchunas DG, Parton WJ (2004) Plant nitrogen dynamics in shortgrass steppe under elevated atmospheric carbon dioxide. Ecosystems 7:147-160

Knapp AK, Briggs JM, Koelliker JK (2001) Frequency and extent of water limitation to primary production in a mesic temperate grassland. Ecosystems 4:19-28

Korner C (2000) Biosphere responses to $\mathrm{CO}_{2}$ enrichment. Ecol Appl 10:1590-1619 
Leakey ADB (2009) Rising atmospheric carbon dioxide concentration and the future of C4 crops for food and fuel. Proc R Soc B 276:2333-2343

Le Houérou HN (1996) Climate change, drought and desertification. J Arid Environ 34:133-185

Luo Y, Melillo J, Niu S et al (2011) Coordinated approaches to quantify long-term ecosystem dynamics in response to global change. Glob Chang Biol 17:843-854

Maestre FT, Salguero-Gomez R, Quero JL (2012) It is getting hotter in here: determining and projecting the impacts of global environmental change on drylands. Philos T Roy Soc B 367:3062-3075

Milchunas DG, Mosier AR, Morgan JA, LeCain DR, King JY, Nelson JA (2005) Elevated $\mathrm{CO}_{2}$ and defoliation effects on a shortgrass steppe: Forage quality versus quantity for ruminants. Agr Ecosyst Environ 111:166-184

Morgan JA, LeCain DR, Mosier AR, Milchunas DG (2001) Elevated $\mathrm{CO}_{2}$ enhances water relations and productivity and affects gas exchange in C-3 and C-4 grasses of the Colorado shortgrass steppe. Glob Chang Biol 7:451-466

Morgan JA, Mosier AR, Milchunas DG, LeCain DR, Nelson JA, Parton WJ (2004a) $\mathrm{CO}_{2}$ enhances productivity, alters species composition, and reduces digestibility of shortgrass steppe vegetation. Ecol Appl 14:208-219

Morgan JA, Niklaus PA, Nippert JB et al (2004b) Water relations in grassland and desert ecosystems exposed to elevated atmospheric $\mathrm{CO}_{2}$. Oecologia 140:11-25

Morgan JA, Milchunas DG, LeCain DR, West M, Mosier AR (2007) Carbon dioxide enrichment alters plant community structure and accelerates shrub growth in the shortgrass steppe. P Natl Acad Sci USA 104: 14724-14729

Morgan JA, Derner JD, Milchunas DG, Pendall E (2008) Management implications of global change for Great Plains rangelands. Rangel 30:18-22

Morgan JA, LeCain DR, Pendall E, Blumenthal DM et al (2011) C4 grasses prosper as carbon dioxide eliminates desiccation in warmed semi-arid grassland. Nature 476:202-205

Moss RH, Edmonds JA, Hibbard KA et al (2010) The next generation of scenarios for climate change research and assessment. Nature 463:747-756

Mote PW, Salathé EP Jr (2009) Future climate in the Pacific Northwest. Clim Chang 102:29-50

Munasinghe M (2009) Sustainable development in practice: sustainomics methodology and applications. Cambridge University Press, Cambridge

Nakićenović N, Davidson O, Davis G et al (2000) Special Report on Emissions Scenarios: A Special Report of Working Group III of the Intergovernmental Panel on Climate Change. Cambridge University Press, Cambridge

Newingham BA, Vanier CH, Charlet TN, Ogle K, Smith SD, Nowak RS (2013) No cumulative effect of 10 years of elevated [CO2] on perennial plant biomass components in the Mojave Desert. Glob Chang Biol 19:1-14

Newingham BA, Vanier CH, Kelly LJ, Charlet TN, Smith SD (2014) Does a decade of elevated [CO2] affect a desert perennial plant community? New Phytol 201:498-504

Norby RJ, Luo YQ (2004) Evaluating ecosystem responses to rising atmospheric $\mathrm{CO}_{2}$ and global warming in a multi-factor world. New Phytol 162:281-293

Owensby CE, Ham JM, Knapp AK, Auen LM (1999) Biomass production and species composition change in a tallgrass prairie ecosystem after long-term exposure to elevated atmospheric $\mathrm{CO}_{2}$. Glob Chang Biol 5:497-506

Peckham SD, Gower ST (2013) Simulating the effects of harvest and biofuel production on the forest system carbon balance of the Midwest, USA. Glob Chang Biol Bioenergy 5:431-444

Polley HW, Johnson HB, Derner JD (2003) Increasing $\mathrm{CO}_{2}$ from subambient to superambient concentrations alters species composition and increases above-ground biomass in a C-3/C-4 grassland. New Phytol 160: 319-327

Polley HW, Jin VL, Fay PA (2012) Feedback from plant species change amplifies $\mathrm{CO}_{2}$ enhancement of grassland productivity. Glob Chang Biol 18:2813-2823

Polley HW, Briske DD, Morgan JA, Wolter K, Bailey DW, Brown JR (2013) Climate change and North American rangelands: trends, projections, and implications. Rangel Ecol Manage 66:493

QiFei H, GePing L, ChaoFan L, Hui Y, YaoLiang C (2013) Modeling grassland net primary productivity and water-use efficiency along an elevational gradient of the Northern Tianshan Mountains. J Arid Land 5:354-365

Randall, DA, RA Wood, S Bony, R Colman, T Fichefet, J Fyfe, V Kattsov, A Pitman, J Shukla, J Srinivasan, RJ Stouffer, A Sumi and KE Taylor (2007) Climate Models and Their Evaluation In: Climate Change 2007: The Physical Science Basis Contribution of Working Group I to the Fourth Assessment Report of the Intergovernmental Panel on Climate Change In: Solomon, SD Qin, M Manning, Z Chen, M Marquis, KB Averyt, M Tignor, Miller HL (eds) Cambridge University Press, Cambridge, United Kingdom and New York, NY, USA 
Reeves MC, Mitchell JE (2011) Extent of coterminous US rangelands: quantifying implications of differing agency perspectives. Rangel Ecol Manage 64:1-12

Reeves MC, Zhao MS, Running SW (2006) Applying improved estimates of MODIS productivity to characterize grassland vegetation dynamics. Rangel Ecol Manage 59:1-10

Reynolds JF, Herrick J, Huber-Sannwald E et al (2007) Global desertification: Building a science for dryland development. Science 316:847-851

Riedo M, Gyalistras D, Fuhrer J (2001) Pasture responses to elevated temperature and doubled CO2 concentration: assessing the spatial pattern across an alpine landscape. Climate Res 17:19-31

Rogelj J, Meinshausen M, Knutti R (2012) Global warming under old and new scenarios using IPCC climate sensitivity range estimates. Nature Clim Chang 2:248-253

Rollins M (2009) LANDFIRE: a nationally consistent vegetation, wildland fire and fuel assessment. Int J Wildland Fire 18:235-249

Running SW, Hunt ERJ (1993) Generalization of a forest ecosystem process model for other biomes, BIOMEBGC and an application for global-scale models. In: Ehleringer JR, Field CB (eds) Scaling Physiological Processes: Leaf to Globe. Academic, San Diego, pp 141-158

Sala OE, Kinzig A, Leemans R et al (2000) Biodiversity - Global biodiversity scenarios for the year 2100. Science 287:1770-1774

Suttle KB, Thomsen MA, Power ME (2007) Species interactions reverse grassland responses to changing climate. Science 315:640-642

Tabor K, Williams JW (2010) Globally downscaled climate projections for assessing the conservation impacts of climate change. Ecol Appl 20:554-565

Tietjen B, Jeltsch F, Zehe E, Classen N, Groengroeft A, Schiffers K, Oldeland J (2010) Effects of climate change on the coupled dynamics of water and vegetation in drylands. Ecohydrology 3:226-237

U.S. Department of Agriculture, Natural Resources Conservation Service (NRCS) (1994) State Soil Geographic (STATSGO) Data Base: Data Use Information. Natural Resources Conservation Service, Fort Worth, Texas

Walther GR (2010) Community and ecosystem responses to recent climate change. Philos T Roy Soc B 365 : 2019-2024

White MA, Thornton PE, Running SW, Nemani RR (2000) Parameterization and sensitivity analysis of the BIOME-BGC terrestrial ecosystem model: net primary production controls. Earth Interact 4:1-85

Woodward FI, Kelly CK (2008) Responses of global plant diversity capacity to changes in carbon dioxide concentration and climate. Ecol Lett 11:1229-1237

Wouter I, Dieleman WIJ, Dukes JS et al (2012) Simple additive effects are rare: a quantitative review of plant biomass and soil process responses to combined manipulations of $\mathrm{CO}_{2}$ and temperature. Glob Chang Biol 18:2681-2693

Zavaleta ES, Shaw MR, Chiariello NR, Thomas BD, Cleland EE, Field CB, Mooney HA (2003) Grassland responses to 3 years of elevated temperature, $\mathrm{CO}_{2}$, precipitation, and $\mathrm{N}$ deposition. Ecol Monogr 73:585-604

Zhang L, Wylie BK, Ji L, Gilmanov TG, Tieszen LL (2010) Climate-driven interannual variability in net ecosystem exchange in the northern Great Plains grasslands. Rangel Ecol Manag 63:40-50 